IZA DP No. 10214

Linguistic and Economic Adjustment among Immigrants in Israel

Barry R. Chiswick

Uzi Rebhun

Nadia Beider

September 2016 


\title{
Linguistic and Economic Adjustment among Immigrants in Israel
}

\author{
Barry R. Chiswick \\ George Washington University \\ and IZA
}

Uzi Rebhun

The Hebrew University of Jerusalem

Nadia Beider

The Hebrew University of Jerusalem

\section{Discussion Paper No. 10214 \\ September 2016}

\author{
IZA \\ P.O. Box 7240 \\ 53072 Bonn \\ Germany \\ Phone: +49-228-3894-0 \\ Fax: +49-228-3894-180 \\ E-mail: iza@iza.org
}

Any opinions expressed here are those of the author(s) and not those of IZA. Research published in this series may include views on policy, but the institute itself takes no institutional policy positions. The IZA research network is committed to the IZA Guiding Principles of Research Integrity.

The Institute for the Study of Labor (IZA) in Bonn is a local and virtual international research center and a place of communication between science, politics and business. IZA is an independent nonprofit organization supported by Deutsche Post Foundation. The center is associated with the University of Bonn and offers a stimulating research environment through its international network, workshops and conferences, data service, project support, research visits and doctoral program. IZA engages in (i) original and internationally competitive research in all fields of labor economics, (ii) development of policy concepts, and (iii) dissemination of research results and concepts to the interested public.

IZA Discussion Papers often represent preliminary work and are circulated to encourage discussion. Citation of such a paper should account for its provisional character. A revised version may be available directly from the author. 
IZA Discussion Paper No. 10214

September 2016

\section{ABSTRACT}

\section{Linguistic and Economic Adjustment among Immigrants in Israel ${ }^{*}$}

This paper analyzes the Hebrew language proficiency, probability of employment, and labor market earnings of immigrants in Israel. It uses the 2010/11 Immigrant Absorption Survey conducted by the Israeli Central Bureau of Statistics. Unique features of the analysis include the study of long-duration immigrants (3 to 20 years), and analyses for: males and females, primary reasons for immigration, the subsidized intensive Hebrew language training program (ulpan), Ethiopian Jews, and Jewish and non-Jewish immigrants from the Former Soviet Union (FSU), in addition to standard immigration, demographic, and human capital variables. Results from multivariate analyses largely accord with the "standard theoretical model" of language proficiency regarding the mechanisms of "exposure", "efficiency", and "economic incentives". Acquaintance with the local language, on its part, increases the likelihood of being employed, and it has positive earnings outcomes. We discuss implications of the findings for public policy which can improve the adjustment of these new immigrants into their new society hence also moderate inter-group tensions.

JEL Classification: F22, J15, J24, J61

Keywords: immigrants, Israel, language proficiency, employment, earnings, motive for immigration, ulpan

Corresponding author:

Barry R. Chiswick

Department of Economics

George Washington University

2115 G Street, NW

Monroe Hall 340

Washington, DC 20052

USA

E-mail: brchis@uic.edu

\footnotetext{
* Earlier versions of this paper were presented at the annual meeting of the Population Association of America, Washington, D. C. (March 31-April 2, 2016); The $4^{\text {th }}$ Ruppin International Conference on Immigration and Social Integration, Israel (May 23-23, 2016); European Society for Population Economics, Berlin (June 15-18, 2016); and the European Population Conference, Mainz (August 31September 3, 2016).
} 


\section{Introduction}

The integration of immigrants into the host society is a long and multi-stage process (Eisenstadt, 1954; Gordon, 1964; Hirschman, Kasinitz, and DeWind, 1999; Park, 1950; Warner and Srole, 1945). To do it successfully immigrants need to acquire several assets (Alba and Nee, 2003). Pivotal among them are the destination language (Kulkarni and $\mathrm{Hu}, 2014$; Lopez, 1999), labor-market experience in the destination (Borjas, 1982; Chiswick, 1979), and citizenship (Portes and Rumbaut, 1996). These three are not independent of each other; rather, language acquisition may abet the other two because as a form of human capital it facilitates the channeling of qualifications into maximum returns (Chiswick and Wenz, 2006; Extra, Spotti, and van Averment, 2009; Grenier, 1982; Shields and Price, 2002). Each of the three assets, and certainly all three together, are likely to boost other dimensions of social and cultural integration (Alba and Logan, 1993; Bean and Stevens, 2003; Guven and Islam, 2015; Kritz and Gurak, 2005; Martinovic et al., 2009; Stevens and Swicegood, 1987)

The purpose of this article is to investigate the adjustment of immigrants in their new country. It focuses on Israel, of which the overwhelming majority of the Jewish population is composed of immigrants or the children of immigrants who arrived from very different parts on the globe (Goldscheider, 2002). We first assess the determinants of proficiency in the local dominant language, namely Hebrew. We then introduce language as an explanatory factor in employment status and labormarket income. These insights are explored comparatively among Jewish and nonJewish immigrants and according to countries or areas of origin. To this end we utilize data from a survey of immigrant absorption carried out by the Israeli Central Bureau of Statistics in 2010 . 
The motivation for this study is fivefold. One is to overcome a major lacuna in the last two Israeli censuses from 1995 and 2008 which, despite a large influx of immigrants to Israel since 1990 from the Former Soviet Union (hereafter: FSU), Ethiopia, and western countries, did not include any questions on language use or skills. A second motivation is that our data cover a long duration of immigrants in Israel of up to twenty years as distinct from most immigration surveys which focus on the first few years. Third, we can decompose the immigrants into several countries or areas of origin. This includes a separate group of immigrants from Ethiopia who arrived in two major waves in 1983 and 1991. Fourth, we introduce non-Jewish immigrants assessing their linguistic and economic integration vis-à-vis their Jewish immigrant counterparts. Fifth, we are able to evaluate the effect of immigration factors rarely measured in census and survey data: explicit reasons for migration (push factors and pull factors), linguistic distance between the origin language and Hebrew, and language instruction for new immigrants. That has implications for policy and can guide other countries that condition visas or citizenship on language skills. Overall, this study stands at the intersection of demography (immigration), culture (language), and economics (earnings), with the last-mentioned reflecting also well-being, which is likely to impact on family formation, family stability, fertility, and parents' investment in their children's human capital.

Notably, the Israeli Law of Return entitles Jews and their non-Jewish immediate relatives to immigrate to the country and receive citizenship automatically upon arrival (Gavison, 2009). From this perspective, all immigrants in Israel begin the absorption process, including language acquisition and labor-market attainment, from a similar point of departure regarding citizenship. 


\section{Theoretical Background}

Linguistic adjustment is not spread evenly among immigrants. It is affected by factors that fall under three mechanisms: "exposure" to the local language, "efficiency" in learning a new language, and "economic incentives" that encourage the acquisition of linguistic skills (Chiswick and Miller, 1995; Mesch, 2003; van Tubergen and Kalmijn, 2009). The components of each may be associated with more than one mechanism.

Exposure relates to opportunities to learn the new language, which are affected by pre-immigration conditions, post-immigration patterns of settlement, and individual affinities (Chiswick and Miller 1995; 2007; Stevens, 1999). This includes, among other things, learning the language of the destination country in the country of origin; learning it upon arrival by attending government-sponsored courses; duration in the new country; reasons for migration (pull or push) that also reflect the intention to stay; for married persons, spouse's place of birth hence his/her mother tongue; the presence of children who bring the new language home from school; and nativity concentration.

Efficiency denotes the process through which exposure to the destination language is converted into language proficiency (Chiswick and Repetto, 2000). The younger people are when they begin to learn a new language, hence, age at immigration, the faster they will be able to master its grammar, syntax, and vocabulary. It is positively associated with education that equips people to study generally and, in particular, to study languages. Language acquisition by immigrants is also likely to be affected by the distance between the home and the host languages. It is easier to learn a new language that is close to one's mother tongue than one that is very distant. It also stands to reason that immigrants will learn the destination 
language more efficiently if they feel they are welcome by the local inhabitants reflected, among other things, in shared religious or ethnic characteristics.

Economic incentives, in turn, view language as a form of human capital that enhances productivity in the labor market and in consumption (Chiswick and Miller, 2007). As such, men, more than women, will acquire the new language as an aid in finding a job (where the gender gap will be greater for those who are married). A similar gap exists between the well-educated and the poorly educated because the former have more opportunities in the labor market if they are proficient in the hostcountry language. Moreover, those who arrived at a younger age will have a greater incentive as they will have more time in which they may gain social and economic returns from an investment in acquiring a new language. Further on the latter logic, proficiency is expected to be lower for immigrants who expect to return to their origin country than among immigrants for whom there is little or no return migration because of political barriers or other reasons (Beenstock, 1996).

That proficiency in the local vernacular enhances economic attainment has been demonstrated in studies by economists and other social scientists (Chiswick and Miller, 2015; Chiswick and Reppeto, 2000; McManus, 1985; Grenier, 1984). As Sherrie Kussoudji concludes, language is "[...] a specific skill necessary for mobility in the labor market" (1988: 225). These findings are consistent across immigration countries as diverse as the U.S. (Chiswick and Wenz, 2006), Canada (Boyd, DeVries and Simkin, 1994), Australia (Guven and Islam, 2015; Waxman, 2001), and Israel (Chiswick and Reppeto, 2000). (For comparisons among these four countries, see: Chiswick and Miller, 1995). Whether the investigation concerns speaking abilities or reading capacity, language is found to be positively associated with employment status (Waxman, 2001), type of occupation (Cohen-Goldner and Eckstein, 2008), and 
earnings (Chiswick and Wenz, 2006). Often, however, it is linked to other individual characteristics triggering correlations that may strengthen or weaken its effect on economic patterns (Berman, Lang, and Silver, 2003). The strength of the effect of language varies among studies and even within a single investigation by the immigrant's national origin (Takenaka, Makamuro, and Ishida, 2015). Notably, earnings are also affected by the international transferability of schooling, foreign labor market experience, and other forms of human capital (Chiswick and Wenz, 2006). Hence, immigrants may follow different trajectories in their economic adjustment depending on their country of origin, among other factors.

\section{Language Acquisition by Immigrants in Israel: Literature Review}

Much attention has been called to the linguistic assimilation of immigrants in Israel. The resulting literature emphasizes the use of census data for immigration during Israel's first thirty-five years (until 1983) and, for lack of linguistic information in later censuses, sample surveys by the Central Bureau of Statistics, research institutes, or independent scientific initiatives. The shift in data sources affected the nature of the analyses: from large samples allowing detailed differentiation among immigrants by countries or small geographic agglomerates, to rough classification by continents of origin; or investigation of immigrants from a single country.

Chiswick and Repetto (2000) use the 1972 Israeli census data to focus on working-age male immigrants. Their findings elicited by various multivariate techniques (OLS, logit, multinomial) are generally consistent, suggesting that education, duration in Israel, young age at immigration, and having children at home - especially if born in Israel - increase the use of Hebrew. By contrast, living in an area with a large concentration of origin-language peers and having gotten married 
abroad, attenuates daily use of Hebrew. Immigrants from North Africa and the Middle East are more likely to speak Hebrew than peers from Eastern Europe; coming from Western Europe, the USA, or other Anglophone countries, deters the use of Hebrew. Speaking Hebrew as a sole or principle language increases annual gross income by 13 percent. Speaking English on a daily basis is even more strongly positively associated with earnings due to the status of English as an international language.

An analysis of data from the 1972 census and a 1970s panel survey on immigration absorption (Beenstock, Chiswick, and Repetto, 2001) yields an assessment of the effect of language distance irrespective of country of origin. These insights postulate that among Jewish immigrants, while being of North African/Middle Eastern origin decreases Hebrew skills, Arabic speakers are the most fluent of all in Hebrew. Immigrants who completed a language training program are significantly more proficient after both one year and three years in Israel. Those weaker in Hebrew upon arrival remained at a disadvantage three years later. After one year in the country, gender differences began to emerge, immigrant women trailing male counterparts.

In 1998, Chiswick and Repetto largely replicated this analysis using 1983 Israeli census data. This study confirmed earlier observations from the 1972 census and revealed that the negative effect on Hebrew proficiency of nativity concentration increases with age at immigration but decreases with level of education and duration in Israel. Immigrants' use of Hebrew can be ranked by place of origin: northern-Africa at the top, followed by Middle East, Eastern-Europe, Western-Europe, the FSU, and Anglophone countries in that order. Those who use Hebrew as a sole or major language out-earn those who use it less often by 11 percent. The highest income 
reward accrues to those who use Hebrew as their primary language and English as a secondary language.

Beenstock (1996, p. 11) also used a 1969-1983 panel survey. His conditional probability models show that immigrants who "could speak well on arrival are likely to achieve a higher level of Hebrew skill after a year in Israel relative to immigrants who could not speak well on arrival". Other positive determinants at the end of the first year are education, young age at immigration, participation in a Hebrew instruction program (with an additional improvement by completing the course), an occupation that entails intensive use of Hebrew, and origin other than North America. The level of Hebrew after three years' duration is conditional on the language skills attained by the end of the first year. Transitional probability models from one level of Hebrew to a higher level yield similar results. Both equations refute the argument that adult immigrants acquire the destination language through their children.

Several studies relating solely to Soviet/FSU immigrants (Beenstock and Ben Menahem, 1997; Mesch, 2003; Remennick, 2004) concur about the positive effect of education, young age at immigration, and duration in Israel on Hebrew skills. Additional variables that are tested in only one or two of these studies and that were found to enhance Hebrew proficiency include pre-immigration Hebrew knowledge, professional work in Israel, two Jewish parents, having resided in a major city in the FSU, and school-aged children at home. Remennick (2004) shows that the effect of duration is significant only for non-aged immigrants (aged 55 and below) and suggests that elderly immigrants are socially isolated, outside the labor force, and inclined to retain their ethnicity. Contrary to his expectations, Mesch (2003) found that ethnic geographic concentration does not deter acquisition of the new language and proactive motivations for immigration do not speed the learning of Hebrew. 
Interestingly, while according to Beenstock and Ben Menahem (1997) women learn Hebrew faster than men, Remennick (2004) did not find gender to be a significant predictor.

Two recent articles analyze data from the 2010/11 Immigrant Absorption Survey carried out by the Central Bureau of Statistics. Raijman, Semyonov, and Geffen (2015) found that, all other things being equal, immigrants from Middle Eastern and North African countries and from Europe and America are likely to have a better command of Hebrew than Soviet/FSU immigrants and immigrants from Ethiopia are the least proficient. Concurrently, immigrants whose mother tongue is Spanish or French are more likely to report a high level of Hebrew fluency than counterparts from other linguistic backgrounds. The authors speculate that the Spanish- and French-speaking communities in Israel are small and, hence, of low ethnic concentration encouraging rapid linguistic assimilation. Moreover, many Francophone immigrants, being of North-African background, have some acquaintance with or past exposure to Arabic, the language closest to Hebrew among all origin languages. That English is a lingua franca in Israel may explain the slow process of English speakers' language acquisition. Other factors positively associated with a good command of Hebrew are being employed, prestigious occupation, education, duration, pre-immigration knowledge of Hebrew, post-immigration Hebrew training, young age at immigration, involvement in social networks populated by Israelis, and Israeli identity. Although the independent variables show similar signs of their effects among all immigrant groups, their levels vary across origins. Ethiopians have the lowest probabilities of exhibiting a good command of Hebrew. In a follow-up study, Semyonov, Raijman, and Maskileyson (2014) show that better Hebrew implies higher earnings. 
South African immigrants are likely to improve their fluency in Hebrew once in Israel (Raijman, 2013). Improvement in their Hebrew proficiency is also positively associated with a young age at arrival, having native-born friends, taking governmental-sponsored Hebrew training, education, ideological motivation for immigration to Israel, and a strong sense of Israeliness. After these affinities are controlled for, gender, partner's ethnicity, and the presence of children at home do not exhibit a statistically significant effect on fluency in Hebrew.

Knowledge of Hebrew among Soviet/FSU immigrant men (Cohen-Goldner and Eckstein, 2008) and women (Cohen-Goldner and Eckstein, 2010) delivers a positive return in the form of better wages. Positive effects are found for different occupational categories. Among men, however, the coefficients are higher for whitecollar jobs than for blue-collar jobs, whereas among women the opposite is the case. Proficiency in English, in turn, increases wages only among those holding whitecollar jobs. Hebrew skills among Soviet immigrant men, whether measured at time of arrival or after a few years in Israel, have a small and overall insignificant effect on earnings (Weiss, Saur, and Gotlibovski, 2003). Similarly, Hebrew fluency has no effect on wage growth of Soviet/FSU immigrants who work in low-skill occupations (Berman, Lang, and Siniver, 2003). For computer technicians and software engineers, in contrast, Hebrew is pivotal in attaining wage convergence with natives.

The above studies largely agree about several individual characteristics that are important determinants of linguistic adjustment in Israel. To a large extent, these characteristics coincide with the perspectives of exposure, efficiency, and economic incentives. Yet, these studies often introduce ties with natives and local identity as independent factors that rather than determining Hebrew-language proficiency, may 
be the outcome of language skills (endogeniety). Such variables may blur the true effect of other explanatory variables.

Models of these types are adopted by, among others, Raijman et al (2015), who use the same data that we use here. However, we exclude variables that reflect social and cultural integration as they are likely to be endogenous. A second difference between our study and Raijman et al. is the treatment of mother-tongues: rather than introducing several major languages as dichotomous variables, we use all languages and measure the distance of each of them from Hebrew. Third, we assess the effects of reasons for immigration that unequivocally reflect pre-immigration conditions. Fourth, we empirically examine the relations between nativity concentration and language proficiency. Fifth, among immigrants from the FSU, we distinguish between Jews and non-Jews; this allows us to introduce religious identity as a determinant of linguistic and economic integration in a country of strong national and religio-ethnic identity. ${ }^{1}$ Further, as described below, we made use of a special set of data of the Immigration Absorption Survey, rather than the Public Use File (PUF), which seems to have been the empirical base for Raijman et al. (2015) and Semyonov et al. (2014). We worked with the Microdata Under Contract (MUC) file which includes several important additional variables, such as spouses' place of birth and the presence of children at home, including whether born in Israel or abroad. The findings of this investigation are discussed in the context of previous studies on the linguistic adjustment of immigrants in Israel and in reference to the general empirical and theoretical literature on this topic.

\section{Data, Variables, and Models}

${ }^{1}$ There were too few non-Jewish immigrants from other countries of origin to study them separately. 


\subsection{The 2010/11 Immigration Absorption Survey (IAS)}

This analysis is based on data from the 2010/11 Immigration Absorption Survey (MUC File) carried out by the Israeli Central Bureau of Statistics. The survey is concerned with immigrants who arrived in Israel between 1990 and 2007. The respondents are a representative sample of the population included in the most recent Israeli census from 2008.

The survey is a stratified sample which attempted to create homogenous groups in regard to variables that correspond with the survey's aims, namely, evaluation of the social and economic integration of immigrants and their views on different aspects of life in the host country; as well as to enable estimation in various profiles. The stratification of the sample made use of three variables: age, period of immigration, and country of origin. Strata (layers) were determined by the intersection of these variables. Overall, 120 sampling strata were defined.

The data were collected through three major methods, namely, mail, internet, and telephone. Respondents were aged 26 to 74 at the time of the survey. The sample is comprised of 3,952 men and women reflecting a response rate of $81 \%$. $^{2}$ We focus on Jewish respondents from Ethiopia (570), rest of Asia/Africa (primarily North African and the Middle Eastern Jews) (270), Latin America (160), Rest of Europe (132), English-speaking developed countries (including South Africa) (206), Former Soviet Union (FSU) Jews $(1,709)$, and non-Jewish respondents from FSU (806). Data were weighted to account for sampling errors and bias associated with non-response and "from problems that arise in the data collection" (CBS, 2013: 21).

\footnotetext{
${ }^{2}$ We are aware of the potential confounding effects of pooling males and females. Yet, this was done here because of the relatively small sample size, which is further reduced when analyzing immigrants from each country/area of origin separately. Where appropriate in the regression analysis gender interaction variables are included to account for differences by gender.
} 


\subsection{Variables}

We address three dependent variables separately. The first is the respondent's ability to speak Hebrew. Respondents were asked: "To what extent are you fluent in Hebrew?" They could check either "very fluent", "fluent", "mediocre", "weak", or "don't know at all". The second variable is employment status which classifies respondents into those who currently work and those who do not (whether worked in the past or never worked in Israel). The third variable is earnings, that is, the respondents' gross wage and salary income from work in the last year for those with positive earned income. Absolute values in local currency (the New Israeli Sheqel/NIS) were transformed to their natural $\log .^{3}$

The explanatory variables for Hebrew-language proficiency are clustered into four major blocks. They are defined as immigration factors, socio-demographic characteristics, linguistic background, and religious identity. Immigration factors included country of origin, age at immigration, duration in Israel, and reasons for immigration. Age at immigration is decomposed into eight dummy intervals: 6-14, $15-19,20-24,25-34,35-44,45-54,55-64$, and 65 and over, with immigrants who were at the ages between 25 and 34 when settled in the country chosen as the reference category. Because the survey was carried out in 2010 on a sample of immigrants that were already in the country in 2008 (see section 4.1 above), the shortest duration is of three years. The data file provided by CBS already classified duration in Israel according to 3-5 years, 6-8, 9-12, 13-16 and 17-20 and we introduce it as a continuous variable.

${ }^{3}$ In 2008, the annual average of the exchange rate was 3.58 NIS to the USD. 
The variable for reason for emigration from the country of origin is based on respondents choosing one main reason among eleven options. These options are: "Zionism", "the desire to live as a Jew in a Jewish State" (pull religious/national); "lack of individual safety in native country", "antisemitism in native country", "the political situation in native country" (push factors); "desire to advance professionally or economically", "desire to ensure children's future" (pull socio-economic); "decisions made by parents, spouse or other family member", "immigration of family members or friends" (family/friends considerations); "could not immigrate to any other country", and "other reason" (other reasons). After several trial runs of introducing different clusters of factors, we found that the best distinction is between the pull religious/national reasons in contrast to all other reasons. There was no difference in the effects among these other reasons. Thus, the analysis was conducted with reason for migration to Israel as a dichotomous variable with the religious/national reasons set to unity and all other reasons set to zero.

The reported primary motive for migrating to Israel varies sharply by country/region of origin. As shown in Appendix Table A1, 77 percent of the Ethiopian immigrants reported ideological reasons (Zionism, nationalistic reasons), as did 65 percent from the English-speaking countries, and 48 percent from the rest of Europe. Family and friends were heavily reported by FSU-Jews (28 percent) and FSU non-Jews (34 percent).

The socio-demographic characteristics are gender, marital status, presence of children under the age of 18 at home, and education. Gender is set to 1 if the respondent was female; male is the reference category. Marital status distinguishes between currently married immigrants and persons not currently married (the reference category) comprised of those who are single, separated, divorced, or 
widowed. If the respondent had a child under the age of 18 at home he/she is coded according to whether the children were born in Israel, had children born in Israel and others born abroad, or children only born abroad, with those with no children becoming the reference category. Education is decomposed into five dichotomous variables: up to high school without matriculation, high school graduation with matriculation (the reference category), post-secondary diploma, bachelors degree, and masters degree or above.

Linguistic background includes participation in intensive governmentsponsored and subsidized Hebrew language instruction for new immigrants (ulpan), language distance, and nativity concentration. All three are continuous measures. Ulpan indicates the number of months of attendance ranging from 0 to 12 and above. Linguistic distance was developed by Isphording and Otten (2014) for a range of languages and as applied here reflects the distance from Hebrew of a myriad of other languages. ${ }^{4}$ Each respondent was assigned the linguistic distance between his/her mother tongue and Hebrew.

A measure of nativity concentration is also included in the model. It is measured as the percentage of immigrants from a given region/country of origin living in the respondent's area of residence out of the total population in that area. In each area in Israel, all respondents from a given region/country of origin were

\footnotetext{
${ }^{4}$ We are indebted to Ingo Isphording for providing the measures of linguistic distance from Hebrew of the other languages. The linguistic distance scores used in this analysis, where a lower score means it is closer to Hebrew: Russian (100.23), Spanish (98.47), English (97.49), French (93.26), Amharic (90.41). If no language was reported, those from the FSU were coded as speaking Russian and those from Ethiopia were coded as Amharic. The small number of cases for which there was no linguistic distance value were deleted from the sample.
} 
assigned the same value of nativity concentration. The residential areas defined for Israel were relatively small geographically.

Group belonging distinguishes between immigrants according to seven major areas of origin and religious identity. This includes Ethiopia, Rest of Asia/Africa (primarily North Africa and Middle East), Latin America, Rest of Europe, English speaking developed countries, FSU-Jewish (the reference category), and FSU-nonJewish. Non-Jews from the FSU are relatives of a Jewish immigrant who are allowed to settle in Israel under its Law of Return.

When assessing the determinants of employment status and earnings, language proficiency is introduced as an explanatory variable. Hebrew proficiency is decomposed into those with no command of Hebrew at all, weak, mediocre (reference category), fluent, and very fluent. We exclude language distance and ulpan from the employment and earnings equations, which the literature does not consider as determinants of economic attainment among immigrants once Hebrew proficiency is held constant.

Summary statistics of the independent variables appear in Table 1.

\subsection{Models}

To evaluate the robustness of the above working hypotheses, we applied multivariate analyses: ordinal logistic regression for language proficiency, logistic regression for employment status, and ordinary least-square (OLS) for earnings. The model for language includes immigration factors, socio-demographic characteristics, language background variables, country of origin and religion. Pooled models for the entire sample were estimated; as well as separate models for Jews (Tables 2-4). In all models, country/area of origin were introduced in order to identify their role as 
distinct from language-of-origin effects (see: Beenstock, Chiswick, and Repetto, 2001).

The basic linguistic model may be formulated as follows:

$\mathrm{LANG}_{\mathrm{j}}=\alpha_{\mathrm{j}}+\beta_{1} \mathrm{X}_{1}+\ldots+\beta_{\mathrm{n}} \mathrm{X}_{\mathrm{n}}+e$

where LANG, the dependent variable, is the odds of having a particular score in Hebrew or less, i.e., prob $($ score $<=\mathrm{j}) /$ prob $($ score $>\mathrm{j}$ ) where $\mathrm{j}$ goes from one to four (the number of levels of language proficiency minus 1), $\alpha_{\mathrm{j}}$ is the threshold values, $\beta_{1} \ldots \beta_{\mathrm{n}}$ are the estimated coefficients for the independent variables $(\mathrm{X})$, and $e$ is the residual.

The associations are presented as logit coefficients that express the probability for lower/higher scores of the trait, namely command in Hebrew, with a (one-unit) change in the respective independent variable. A negative coefficient indicates that an explanatory variable is likely to result in a lower score of language proficiency; a positive coefficient attests to the likelihood of higher scores. A pseudo- $R^{2}$ (Negelkerke $R^{2}$ ) is a measure of the model's overall explanatory power.

For assessing the determinants of employment status we apply binary logistic regression. The probability that a respondent works or does not work is expressed as:

\section{$\mathrm{Z} \underline{\text { Prob (working) }}=a+B_{1} \mathrm{X}_{1} \ldots+B_{\mathrm{n}} \mathrm{X}_{\mathrm{n}}+B_{\mathrm{ij}} \mathrm{X}_{\mathrm{i}} \mathrm{X}_{\mathrm{j}}+\mathrm{e}$}

Prob (not working)

The estimated coefficients $(B)$ of the independent variables $(\mathrm{X})$ "are measures of the changes in the ratio of the probabilities" (odds ratios) (Hair et al., 1995). Originally, they are given in logarithms and the computer software presents the antilog of the values which is easier to interpret. Notably, this model also includes interaction terms $\left(\mathrm{X}_{\mathrm{i}} \mathrm{X}_{\mathrm{j}}\right)$ of gender by marital status and gender by children to tell us if the partial effect of these familial characteristics on the dependent variable varies by gender. 
The modeling of the effect of Hebrew language skills on earnings adopts the human capital earnings function. It links the natural logarithm of earnings to the independent variables. Here, as well, we present separate equations for a pooled model for the immigrant population as a whole and separately for Jews. The model for earnings is formulated as follows:

LNEARN $_{\mathrm{i}}=\mathrm{a}+\mathrm{B}_{1} X_{1}+\ldots \mathrm{B}_{\mathrm{n}} X_{\mathrm{n}}+e$

where LNEARN, the dependent variable, is the predicted amount of (ln)earnings, "a" is a constant, $\mathrm{B}$ is the unstandardized coefficient (amount of addition to, or subtraction from, constant earnings for a one-point change in $\mathrm{X}$ ), $\mathrm{X}$ is the observed value of the respective independent variable, and $e$ is the residual or prediction error. The explanatory power of the model is provided by the coefficient of determination $\mathrm{R}^{2}$.

For each of the dependent variables we show two models: the first model is of Jewish immigrants alone; the second model incorporates non-Jewish immigrants (from the FSU). Regressions for non-Jewish FSU immigrants are reported in the Appendix A.2. This allows an assessment of the role of religious identity for immigrant adaptation in Israel.

\section{Descriptive Overview}

Figure 1 presents the distribution of proficiency in Hebrew among the total immigrant population in the sample overall and separately for seven subgroups of immigrants. Overall, in 2010, some 54.6\% reported being fluent or very fluent in Hebrew, almost equally divided between the two categories. Another one-fourth (26.6\%) had medium fluency in Hebrew; the remaining one-fifth had weak proficiency $(14.2 \%)$ or none at all $(4.5 \%)$. 
This overall profile, however, masks substantial inter-group variations. Immigrants from Ethiopia, for example, languish at the weak end of Hebrew proficiency while those from Latin America, rest of Europe, and English-speaking countries have the strongest proficiency. Thus, only $13.8 \%$ of immigrants from Ethiopia reported that they speak Hebrew fluently and 32.2\% described their Hebrew as very fluent or $46.0 \%$ jointly; the rate among immigrants from Latin America is $78.1 \%$, from rest of Europe $79.7 \%$, and from English-speaking countries $67.4 \%$. In other words, the proportion of immigrants who speak Hebrew fluently or very fluently is about one and a half times or more as high among the latter three groups than their counterparts from Ethiopia. Immigrants from the rest of Asia/Africa and from the FSU fall somewhere in between, with a moderate level of Hebrew. Thus, slightly more than half (54.3\%) of immigrants from elsewhere in Asia/Africa described their Hebrew as fluent or very fluent, and $55.1 \%$ of Jewish immigrants from the FSU did the same. Notably, Jewish immigrants from the FSU have a somewhat better command of Hebrew than FSU non-Jews (46.0\%).

(Figure 1, about here)

The differences among immigrant subgroups are especially salient shortly after arrival in Israel (Figure 2). Three to five years after immigration, the proportion of immigrants from Latin America who spoke Hebrew fluently or very fluently was twice that of immigrants from the rest of Asia/Africa, rest of Europe, or the FSU and almost five times higher than that of Ethiopian immigrants. Similarly, a relatively high proportion (43.2\%) of new immigrants from English-speaking countries reported a good command of Hebrew. With a longer duration in Israel all subgroups, hence the total immigrant population as well, experienced improvement in speaking Hebrew. 
The differences between subgroups narrowed during this process. Thus, for example, after seventeen to twenty years in the country, the differential between immigrants from Latin America, on the one hand, and each of the immigrant groups from Ethiopia and FSU-Jews, on the other hand, in the proportion who spoke Hebrew fluently/very fluently dropped to 22 percentage points; and was only 14.7 percentage points greater than immigrants from the rest of Asia/Africa. Interestingly, while shortly after arriving in Israel Jewish immigrants from the FSU spoke Hebrew better than non-Jews, the latter group quickly closed the gap and after seventeen to twenty years in the country the proportion of non-Jewish FSU immigrants who spoke Hebrew fluently or very fluently overtook those of the Jewish Soviet immigrants.

(Figure 2, about here)

Attention is now directed to the second dependent variable, namely, employment status. Slightly more than three-fourths (79\%) of the sample population worked at the time of the survey. Inter-group variations range from as low as $66.9 \%$ among immigrants from Ethiopia to as high as $86.1 \%$ among immigrants from Latin America. Non-Jewish Soviet immigrants have a slightly higher employment probability $(85.1 \%)$ than their Jewish peers $(82.5 \%)$.

(Figure 3, about here)

As far as labor-market income is concerned, the average gross annual earnings from work in Israel in 2008 (for those with earnings) was 74,331 NIS (Figure 3). In this respect, also substantial differences among immigrant groups were found. NonJewish immigrants from the FSU earned the least $(63,733)$. Immigrants from Ethiopia had only a slightly higher annual income of 65,016 NIS. The group at the highest end of the income ladder are immigrants from English-speaking countries who earned one and a half times more (109,937 NIS). All other immigrant groups were situated in the 
income rank of 75,000 NIS to 86,000 NIS. Jewish immigrants from the FSU earn approximately 13,000 NIS more than their non-Jewish Soviet counterparts. Multivariate analysis will show whether, after controlling for immigration, sociodemographic, and language factors, religious identity per se is associated with earnings in Israel among those from the FSU.

(Figure 4, about here)

\section{Multivariate Analysis}

\subsection{Determinants of Hebrew-Language Proficiency}

What may explain variations in language proficiency? To what extent are they determined by immigration factors, socio-demographic characteristics, language background, and origin? Does religious identity matter? And what is the overall power of these variables in explaining variations in command of Hebrew among immigrants in Israel?

A major determinant of Hebrew-language proficiency is age at immigration (Table 2). Young age at immigration among adults enhances proficiency. The effect is non-linear. The marginal effect is stronger at younger ages and weakens as age at immigration increases; it turns negative among immigrants who are older than the benchmark age of 25-34 upon arrival. Duration improves language proficiency. Each addition of three to four years in the country increases the ability to speak Hebrew by approximately 0.06 of the unit.

Immigrants who were motivated by religious/nationalistic considerations exhibit a better command of Hebrew as compared with their counterparts who were pushed or pulled by economic or familial incentives. It stands to reason that Jews with strong ties to Judaism and to Israel had some knowledge of Hebrew prior to their immigration. 
(Table 2, about here)

Immigrant women exhibit better Hebrew skills than immigrant men. Judging by the size of the coefficients, gender differences are more salient in the second model, which includes non-Jewish immigrants. The non-Jewish respondents, being from the FSU, presumably reflect the strong motivation of Soviet women to work (Rebhun 2008). Married immigrants have weaker command of Hebrew than singles (the reference category). Being unassisted, singles must learn the new language quickly to take care of various aspects of absorption. Even so, the differences are not significant. In addition, spouses' nativity, whether similar or different, is immaterial in the acquisition of the new language. The interpretation of this is that the familial sphere is neither an obstacle nor a springboard for learning a new language. Rather, external environmental factors, included under the rubric of "immigration factors" and "language background", play a more pivotal role in the acquisition of the new language.

Another familial dimension is the presence of children at home. Compared with those with no children, neither having native-born children nor having children born both in Israel and abroad, improves the immigrant's command of Hebrew. The children-language proficiency relation, however, is negative and statistically significant in the total sample (and in the sample of non-Jews from the FSU) among respondents all of whose children were born abroad. That this relation is slightly weaker for the Jewish sample than for the total sample (seen both in the size of the coefficient and its level of significance) suggests that the former group is more likely to encourage its children to speak the new language and therefore speed their integration into schools and social circles, hence also facilitating the parents' linguistic adjustment as well. 
Higher education is positively associated with language proficiency. Command of Hebrew improves commensurate with education among those in the Jewish, total and FSU non-Jewish samples. Among people with academic education, the coefficients are slightly higher in the total sample than among Jews only.

The Hebrew-language instruction program provided by the host authorities (ulpan) seems to help. Each month in ulpan improves fluency in Hebrew (by 0.08 unit scale in the Jewish sample). Thus, approximately twelve months should enable an attendee to advance from the level of Hebrew at which he/she started to the next level. The ulpan effect is much larger for non-Jewish immigrants than for Jewish immigrants. Remember that Jewish immigrants arrive with a better command of Hebrew than do non-Jewish immigrants. Thus, we may postulate that the ulpan syllabus is most appropriately tailored to immigrants who have a relatively low or no command of Hebrew at arrival.

The greater the distance between the origin language and Hebrew, the weaker the command of the latter; yet, these relations are insignificant. This is in part due to holding constant country/region of origin. By contrast, living in an area in Israel where many others speak the same origin language is associated with a poorer command of Hebrew. This may arise because living in a minority language enclave inhibits developing Hebrew proficiency or because those who become more proficient in Hebrew move out of the origin language neighborhood.

All other factors being equal, immigrants from Ethiopia are less fluent in Hebrew than members of the reference group, Jewish immigrants from the FSU. Immigrants from other areas have a better command of Hebrew vis-à-vis the Jewish Soviet immigrants. Judged by the size of the coefficients, immigrants from Latin American are ranked highest, followed by immigrants from the rest of Asia/Africa, 
English-speaking countries, and from the rest of Europe (though the latter group's relations with proficiency in Hebrew is statistically insignificant). It is well documented that the overwhelming majority of Jewish children in Latin America are enrolled in Jewish day schools, in which the curriculum includes a heavy load of Hebrew instructions (JPPI, 2011). Immigrants from the rest of Asia/Africa, Englishspeaking countries, and the rest of Europe share a rather strong religious identification that probably included enrollment in Jewish schools, familiarity with the Jewish prayer-book, and early visits to Israel (especially among those from America and Europe), hence some pre-immigration knowledge of Hebrew. Jews from Ethiopia and the FSU, in contrast, were limited in their exposure to Judaism generally and to the Hebrew language in particular in their origin countries.

Immigration, socio-demographic, language, and origin factors held constant, non-Jews from the FSU (Model 2) exhibit a lower level of Hebrew, (by 0.188 on a 1-4 scale at $\mathrm{p}<.05)$. Starting at a lower level, they do experience a steeper increase in proficiency with duration in Israel. Thus, FSU non-Jews narrow the gap with their Jewish counterparts as time in Israel elapses.

The independent variables are efficient in explaining variations in Hebrew proficiency. They account for $58.2 \%$ of the variation for the Jewish immigrant population. These variables are slightly more efficient in explaining variation after incorporating the non-Jewish Soviet immigrants (59.4\%). 


\subsection{Determinants of Employment Status}

Table 3 presents unstandardized coefficients derived from binary logistic regression models that predict working versus not working. The analysis is restricted to people of working age, who were aged 64 or younger when they arrived in Israel and at the time of the survey. The models are modified slightly to combine all respondents not currently married into one group (currently married=0, not married=1). All respondents who have children under the age of 18 at home are combined into one category ( children $=0$, no children $=1$ ). Following these changes, we introduced interaction terms between gender and the variables for marital status and children.

The effects of immigration factors show an overall higher probability of working for those who immigrated at a younger age. Somewhat surprisingly, the likelihood of being employed declines with duration in the country. ${ }^{5}$ Recently arrived immigrants have greater odds of being economically active than longer duration immigrants.

The motivation of Jews to move to Israel is not associated with employment status in Israel. After non-Jewish immigrants are added, however, those who moved due to religious/national incentives are more likely to be working than their counterparts who were drawn to the country by other factors. In the analysis limited to non-Jewish FSU immigrants, those who reported religious/national motives for moving were less likely to be employed.

(Table 3, about here)

\footnotetext{
${ }^{5}$ Recall that the immigrants would have been in Israel for a minimum of three years. By then they would have completed their Ulpan program and overcome initial labor market information problems of new immigrants.
} 
Being a woman decreases the probability of employment. Among men and among women, marital status per se has no significant effect on the probability of being employed. The effect of having no children at home is, however, highly statistically significant. It lowers the probability of being employed. There are no differences in employment probability between unmarried men and unmarried women. Yet, immigrant women with no children at home are more successful in joining the economically active sector $(B=0.687$ at $\mathrm{p}<.01)$. In other words, overcoming the obstacles associated with family obligations eliminates gender inequality for immigrant women in Israel.

Advanced education, i.e., master's degree and higher, does improve the chances of finding a job but the effect is not statistically significant. Proficiency in Hebrew, however, does significantly influence the employment probability. Those who are fluent or very fluent in Hebrew are significantly more likely to be employed than immigrants whose speaking proficiency is mediocre, and the employment probability is even lower among those with weak or total lack of command of Hebrew.

Recall that the nativity concentration index, a measure of enclave effects, was constructed on the basis of small geographic areas in a geographically small country. Where one lives in relation to others of the same origin has no significant effect on the probability of being employed.

The coefficients for all immigrant groups, with the exception of Ethiopians, show lower probabilities of being employed than the reference category of Soviet Jewish immigrants. For three of the five groups - immigrants from English speaking countries, from the rest of Europe, and from the rest of Asia/Africa - the relations are statistically significant (the latter at $\mathrm{p}<.10$ ). That people of Soviet background are 
strongly inclined to work is even more evident among non-Jews. According to the analysis for the total sample, non-Jewish FSU immigrants in Israel are about 34\% more likely to work than their Jewish FSU counterparts. ${ }^{6}$

The independent variables were able to explain approximately one-fifth of the variation in the employment status of immigrants in Israel. This is a much weaker explanatory power than that exhibited by the previous models for proficiency in Hebrew. Other considerations, presumably not only on the individual level but also on the macro social and economic level of the country and the specific area of residence, and which are not indexed by the survey data, presumably account for the remaining large part of the reasons why some immigrants work and others do not.

\subsection{Determinants of Earnings}

Another important economic aspect of immigrants' adjustment is earnings. The analysis is restricted to people who worked throughout the entire reference year and reported positive labor income. These restrictions somewhat reduced the sample size of each immigrant group (Table 4).

Several of the explanatory variables figured importantly in the earnings model (Model 1). They include tenure, gender, presence of children, education, language proficiency, and nativity concentration. As duration in the new country increases, earnings are likely to increase. Net of other measured characteristics, women earn less than their male counterparts. But the gender effect does not vary significantly by the presence of children in the home. Immigrants who do not have children at home earn

\footnotetext{
${ }^{6}$ Notably, a model not shown here introduced interaction terms of origin by Hebrew-language proficiency. All coefficients were statistically insignificant. In other words, variations among origin groups by level of Hebrew do not affect employment status beyond the separate association of each of the variables Hebrew language and origin with employment status.
} 
more than those with children. This is true for both immigrant men and women, as suggested by the insignificant effect of the interaction term of female by no children. Somewhat surprisingly immigrants with an advanced academic degree (masters level or higher) do not earn significantly more than those with only high school matriculation. This may be due to difficulties in the transferability to Israel of skills learned abroad. Being fluent in Hebrew increases earnings, yet being very fluent or with no knowledge of the language does not significantly affect earnings compared to those with a moderate command of the language.

(Table 4, about here)

Immigrants from English-speaking countries are at an earnings advantage over Jewish immigrants from the FSU, by about 40 percent. Immigrants from other areas of origin earn more than FSU Jews, except those from Ethiopia, who earn less, but the differences are not statistically significant. When key factors of immigration, sociodemography, education, and language are held constant, non-Jewish Soviet immigrants still earn about 16 percent less than their Jewish peers from the FSU.

Overall, the insights from this analysis are that two immigrant groups are at an earnings disadvantage: Ethiopian Jews and FSU non-Jews, with immigrants from the English-speaking countries having the highest earnings. ${ }^{7}$ Ethiopian immigrants have low earnings, but this appears to be explained by their very low level of formal schooling and poorest command of Hebrew.

Consistent with other studies of immigrant earnings, the models were able to explain a low proportion of the variation in earnings. Still, the incorporation of the

\footnotetext{
${ }^{7}$ Footnote 6 above is also true for earnings.
} 
non-Jewish Soviet immigrants almost doubled the explanatory power from $3.3 \%$ in the first model to $5.5 \%$ in the second model.

\section{Conclusions}

This article explored the determinants of destination-language proficiency among immigrants in Israel, and further asked how linguistic qualifications are channeled into economic returns, in particular employment and labor-market earnings. The study introduced separate models for Jewish immigrants and for the total immigrant population which includes also non-Jews from the FSU. To this end, we used data from the 2010 Immigrant Absorption Survey. It inquired into reasons for immigration, settlement patterns, and adjustment to the new country, including language, hence filling a major data gap in the last two censuses (from 1995 and 2008) which ignored this topic.

Immigrants who were initially very poor in Hebrew proficiency - those from Ethiopia, the rest of Asia/Africa, and the FSU - advanced more quickly than their counterparts from Latin America and English-speaking countries, who were more fluent shortly after arrival. Although the inter-group gaps narrowed over time they remained rather salient even twenty years after immigration. The younger the immigrants were when they reached Israel, the more effectively they mastered the new language. Time at destination matters; it is positively associated with command of the new language. People who were motivated to move to Israel because of religious/national reasons exhibit higher levels of Hebrew than those who moved for other economic or familial considerations.

Women are at a linguistic advantage relative to men. Family composition, reflected in spouse's nativity status (whether born in the same area as the respondent or in a different area) is not significant for learning the new language. Yet, if all 
children were born abroad the pace of learning the new language is slower as compared with those with no children or at least some children born in Israel.

Secular education and the study of Hebrew in special programs sponsored by the Israeli government (ulpan) are positively associated with fluency. Nativity concentration is negatively associated with Hebrew proficiency. Further research is needed to determine whether this is due to those with poorer proficiency preferring to live in neighborhoods with many others from their origin or whether it is due to origin language enclaves inhibiting improvements in Hebrew.

Regardless of key immigration and individual characteristics, immigrants from Ethiopia and the FSU are less proficient in Hebrew than their counterparts from the rest of the world. Non-Jewish immigrants from the FSU are even less proficient in Hebrew than FSU Jews.

This empirical evidence largely accords with the "standard theoretical model" of language proficiency. Exposure factors, such as enrollment in a special Hebrew language program for new immigrants, a longer duration in Israel, not having children born abroad, and not living in ethnic enclaves, are associated with greater Hebrewlanguage proficiency. People who immigrated to Israel due to the pull factors of religious or nationalistic motives, are more proficient in Hebrew than those who reported other reasons. They are likely to have prepared for the move to a Hebrew speaking country.

Efficiency, proxied here by a younger age at immigration and a higher level of formal education, was helpful in learning Hebrew. Another variable, which is understood in terms of efficiency, is the distance between origin and host country language. While having a negative effect on Hebrew proficiency, this variable was not statistically significant. Economic incentives, which are assumed to operate 
especially among people of a specific socio-demographic profile, in particular those who have low rates of return migration or emigration (such as Soviet Jews) and the well-schooled, proved to be associated with greater Hebrew proficiency.

Fluency in the local language increases the likelihood of being employed. Further, for those who work, acquaintance with the local language has positive earnings outcomes. While immigrant women improve their language proficiency faster than immigrant men, they tend to have a lower employment probability and earn less

Irrespective of individual characteristics, not being Jewish is negatively associated with Hebrew proficiency and earnings, but is associated with a higher probability of being employed. It is unclear whether this effect on proficiency and earnings reflects less investment in Israel-specific human capital, weaker labor market networks, or some other unmeasured factors, including discrimination.

The nativity concentration variable measures the proportion of the population in the immigrants' area of residence in Israel from the same country or region of origin. Immigrants living in an area with many others from their origin are associated with poorer proficiency in Hebrew, perhaps, in part, because they communicate on a daily basis more in their origin language or because of a preference for living among others from their origin among those with poorer proficiency. There are no nativity concentration effects on employment. Yet, nativity concentration increases earnings. Israel is a geographically small country and most Israelis live outside of the southern desert region. One could have expected that with the good transportation network many Israeli immigrants will view their relevant labor market as extending beyond the area in which they live. Still, the nativity concentration ratio has a positive effect on earnings, other variables being the same. 
The study has important implications for public policy. First, it further demonstrates the importance of Hebrew language training, and the ulpan program, for economic success in Israel. Second, it indicates the importance of helping immigrants transfer their pre-immigration skills, including their educational credentials, to be relevant for the Israeli labor market. Third, it highlights the disadvantages of two small immigrant groups, namely Ethiopian Jews who come from one of the poorest and least developed countries, and non-Jews from the Former Soviet Union. Because of their different origins, the causes of their disadvantages may differ. Policies to improve their Hebrew proficiency will not only improve the adjustment of these immigrants into the Israeli society, they will also moderate inter-group tensions and enhance the human capital stock in Israel.

\section{References}

Alba, Richard D. and John, Logan. 1993. "Migration Proximity to Whites in Suburbs: An Individual-Level Analysis of Segregation". American Journal of Sociology 98: $1388-1427$.

Alba, Richard D. and Victor, Nee. 2003. Rethinking the American Mainstream: Assimilation and Contemporary Immigration. Cambridge, MA: Harvard University Press.

Bean, F. D. and G. Stevens. 2003. America's Newcomers and the Dynamics of Diversity. New York: Russell Sage Foundation.

Beenstock, Michael. 1996. 'Failure to Absorb: Remigration by Immigrants to Israel". International Migration Review 30(4): 950-978.

Beenstock, Michael. (1996). "The Acquisition of Language Skills by Immigrants: The Case of Hebrew in Israel". International Migration 34(1): 3-30. 
Beenstock, Michael and Yitzhak, Ben Menahem. (1997). "The Labour Market Absorption of CIS Immigrants to Israel: 1989-1994". International Migration 35(2): $187-224$

Beenstock, Michael, Barry R. Chiswick, and Gaston L. Repetto. (2001). "The Effect of Linguistic Distance and Country of Origin on Immigrant Language Skills: Application to Israel". International Migration 39(3): 33-60.

Berman, E., K. Lang, and E. Siniver. 2003. "Language-Skill Complementary: Returns to Immigrant Language Acquisition". Labor Economics 10(3): 265-290.

Borjas, G. J. 1982. "The Earnings of Male Hispanic Immigrants in the United States". Industrial and Labor Relations Review 35(3): 343-353.

Boyd, Monica, J. DeVries, and K. Simkin. 1994. "Language, Economic Status and Integration". In: H. Adelman, A. Borowski, M. Burstein, and L. Foster (eds.), Immigration and Refugee Policy: Australia and Canada Compared. Carlton: Melbourne University Press, vol. II, pp. 549-577.

Central Bureau of Statistics. 2008. Statistical Abstract of Israel, 2008. Jerusalem.

Central Bureau of Statistics. 2013. Immigration Absorption Survey 2010-2011:

Selected Findings (Publication no. 1520). Jerusalem.

Central Bureau of Statistics, 2014. Statistical Abstract of Israel, 2014. Jerusalem.

Chiswick Barry R. 1979. "The Economic Progress of Immigrants: Some Apparently Universal Patterns. In: W. Fellner (ed.), Contemporary Economic Problems. Washington: American Enterprise Institute, pp. 357-399.

Chiswick, Barry R. (1998). "Hebrew Language Usage: Determinants and Effects on Earnings among Immigrants in Israel". Journal of Population Economics 11: 253271. 
Chiswick Barry R. and Paul W. Miller. 1995. "The Endogeneity between Language and Earnings: International Analyses". Journal of Labor Economics 13: 246-288.

Chiswick Barry R. and Paul W. Miller. 2007. The Economics of Language: International Analyses. London: Routledge.

Chiswick Barry R. and Paul W. Miller. 2015. "International Migration and the Economics of Language". In: Barry R. Chiswick and Paul M. Miller (eds.), Handbook of the Economics of International Migration. Elsevier, pp. 211-269.

Chiswick, Barry R. and G. Repetto. 2000. "Immigrant Adjustment in Israel: Literacy and Fluency in Hebrew and Earnings". In S. Slobodan (ed.) International Migration: Trends, Policy and Economic Impact. New York: Routledge, pp. 204-228.

Chiswick Barry R. and M. Wenz. 2006. "The Linguistic and Economic Adjustment of Soviet Jewish Immigration in the United States, 1980 to 2000". Research in Labor Economics 24: 179-216.

Cohen, Yinon, Yitzhak, Haberfeld, and Tali, Kristal. 2004. Ethnicity and Mixed Ethnicity: Educational Gaps among Israeli-Born Jews. Discussion Paper No. 5-2004, Tel-Aviv University: The Pinhas Sapir Center for Development.

Cohen-Goldner, S. and Z. Eckstein. (2008). "Labor Mobility of Immigrants: Training Experience, Language, and Opportunities". International Economics Review 49(3): 837-872.

Cohen-Goldner, S. and Z. Eckstein. (2010). "Estimating the Return to Training and Occupational Experience: The case of Female Immigrants". Journal of Econometrics, 156: 86-105.

Dahan, Momi. 2013. "The Israeli Economy: Has the Melting Pot Succeeded?" Economic Quarterly 60(1-4): 107-152; 
DellaPergola, Sergio. 1984. "On the Differential Frequency of Western Migration to Israel". Studies in Contemporary Jewry. Oxford and New York: Oxford University Press, vol. 1, pp. 292-315.

DellaPergola, Sergio. 2004. "Demography in Israel at the Dawn of the Twenty-First Century". In: Uzi Rebhun and Chaim I. Waxman (Eds.), Jews in Israel: Contemporary Social and Cultural Patterns. Hanover and London: University Press of New England/Brandeis University Press, pp. 20-44.

DeelaPergola, Sergio. 2009. "International Migration of Jews". In: Eliezer Ben-Rafael and Yitzhak Sternberg (Eds.), Transnationalism: Diasporas and the Advent of A New (Dis)order. Leiden and Boston: Brill, pp. 213-236.

Eisenstadt, Shmuel N. 1954. The Absorption of Immigrants. London: Routledge and Paul.

Extra, G., M.A. Spotti, and P. van Avermaet, ed. 2009. Language Testing, Migration, and Citizenship. London and New York: Continuum.

Friedlander, Dov, Barbara, Okun, Zvi, Eisenbach, and L. Elmakias. 2002. "Immigration, Social Change, and Assimilation: Educational Attainment among Birth Cohorts of Jewish Ethnic Groups in Israel, 1925-29 to 1965-69". Population Studies 56(2): 135-150.

Gavison, Ruth. 2009. 60 Years to the Law of Return: History, Ideology, Justification. Jerusalem: Metzilah Center (in Hebrew).

Goldscheider, Calvin. 2002. Israel's Changing Society: Population, Ethnicity, \& Development. Boulder, CO: Westview Press (Second edition).

Gordon, Milton M. 1964. Assimilation in American Life: The Role of Race, Religion, and National Origin. New York: Oxford University Press. 
Grenier, G. 1984. "The Effects of Language Characteristics on the Wages of Hispanic-American Males". The Journal of Human Resources 19: 35-52.

Grenier, G. 1982. Language as Human Capital: Theoretical Framework and Application to Spanish-Speaking Americans. Ph.D. Dissertation. Princeton, NJ: Department of Economics, Princeton University.

Guven, Cahit, and Asadul, Islam. 2015. "Age at Migration, Language Proficiency, and Socioeconomic Outcomes: Evidence From Australia". Demography 52(2): 513542.

Herzl, Theodore. 1934. The Jewish State: An Attempt at a Modern Solution to the Jewish Question, translation Sylvie d'Avigdor, $2^{\text {nd }}$ edition, London.

Hirschman, Charles, Philip, Kasinitz, and Josh, DeWind. 1999. "Immigrant Adaptation, Assimilation, and Incorporation", In: Charles Hirschman, Philip Kasinitz, and Josh DeWind (eds.) The Handbook of International Migration: The American Experience. New York: Russell Sage Foundation, pp. 127-136.

Isphording, Ingo E. and Sebastian, Otten. (2014). "Linguistic Barriers in the Destination Language Acquisition of Immigrants". Journal of Economic Behavior and Organization 105: 30-50.

Jewish People Policy Institute. 2011. Annual Assessment, 2010. Jerusalem, p. 14

Kossoudji, S. 1988. "English Language Ability and the Labor Market Opportunities of Hispanic and East Asian Immigrant Men". Journal of Labor Economics 6(2): 205228.

Kritz, Mary M. and Douglas T. Gurak. 2005. "Immigration and a Changing America". In: R. Farley and J. Haaga (eds.), The American People: Census 2000. New York: Russell Sage Foundation, pp. 259-301. 
Kulkarni, Veena S. and Xiaohan Hu. 2014. "English language Proficiency among the Foreign Born in the United States, 1980-2007: Duration, Age, Cohort Effects". International Migration Review 48(3): 762-800.

Lopez, David E. 1999. "Social and Linguistic Aspects of Assimilation Today". In: Charles Hirschman, Philip Kasinitz, and Josh DeWind (eds.) The Handbook of International Migration: The American Experience. New York: Russell Sage Foundation, pp. 212-222.

Martinovic, B., F. van Tubergen, and I. Maas. 2009. "Dynamics of Interethnic Contact: A Panel Study of Immigrants in the Netherlands". European Sociological Review 25: 303-318.

McManus, W. 1985. "The Labor Market Costs of Language Disparity: An Interpretation of Hispanic Earnings Differences". American Economic Review 75: 818-827.

Mesch, Gustavo S. 2003. "Language Proficiency among New Immigrants: The Role of Human Capital and Societal Conditions". Sociological Perspectives 46(1): 41-58.

Park, Robert R. 1950. Race and Culture. Glencoe: Free Press.

Portes, Alejandro and Ruben G. Rumbaut. 1996. Immigrant America: A Portrait. Berkeley: University of California Press ( $2^{\text {nd }}$ edition).

Raijman, Rebeca. (2013). "Linguistic Assimilation of First-Generation Jewish South African Immigrants in Israel". Journal of International Migration and Integration 14(4): 615-636.

Raijman, Rebeca, Moshe, Semyonov, and Rona, Geffen. (2015, forthcoming). "Language Proficiency among Post-1990 Immigrants in Israel". Journal of Ethnic and Migration Studies. 
Rebhun, Uzi. 2008. "A Double Disadvantage? Immigration, Gender, and Employment Status in Israel". European Journal of Population 24(1): 87-113.

Rebhun, Uzi. 2009. "Immigration, Ethnicity, and Housing-Success Hierarchies in Israel". Research in Social Stratification and Mobility 27: 219-243.

Remennick, Larissa. (2004). "Language Acquisition, Ethnicity and Social Integration among Former Soviet Immigrants of the 1990s in Israel". Ethnic and Racial Studies 27(3): 431-454.

Semyonov, Moshe, Rebeca, Raijman, and Dina, Maskileyson. (2015). "Ethnicity and Labor Market Incorporation of Post-1990 Immigrants in Israel". Population Research and Policy Review 34(3): 331-359.

Shields, M. and S. W. Price. 2002. "The Effect of Language Fluency on the Wages of Immigrant Men in England". Journal of Population Economics 15: 171-185.

Stevens, G. 1999. "Age at Immigration and Second Language Proficiency among Foreign-Born Adults". Language in Society 28: 555-578.

Stevens, G. and G. Swicegood. 1987. "The Linguistic Context of Ethnic Endogamy". American Sociological Review 52: 73-82.

Takenaka, Ayumi, Makiko, Nakemuro, and Kenji, Ishida. (forthcoming, 2015). "Negative Assimilation: How Immigrants Experience Economic Mobility in Japan". International Migration Review.

Van Tubergen, F. and M. Kalmijn. 2005. "Destination-Language Proficiency in Cross-National Perspective: A Study of Immigrant Groups in Nine Western Countries". American Journal of Sociology 110: 1412-1457.

Warner, W. Lloyd and Leo Srole. 1945. The Social Systems of American Ethnic Groups. New Haven, CT: Yale University Press. 
Waxman, Peter. 2001. "The Economic Adjustment of Recently Arrived Bosnian, Afghan, and Iraqi Refugees in Sydney, Australia". International Migration Review 35(2): 472-505.

Weiss, Yoram, Robert M. Sauer, and Menahem, Gotlibovski. (2003). "Immigration, Search, and Loss of Skill". Journal of Labor Economics 21(3): 557-591. 
Figure 1.

Hebrew Speaking Fluency by Country/Area of Origin

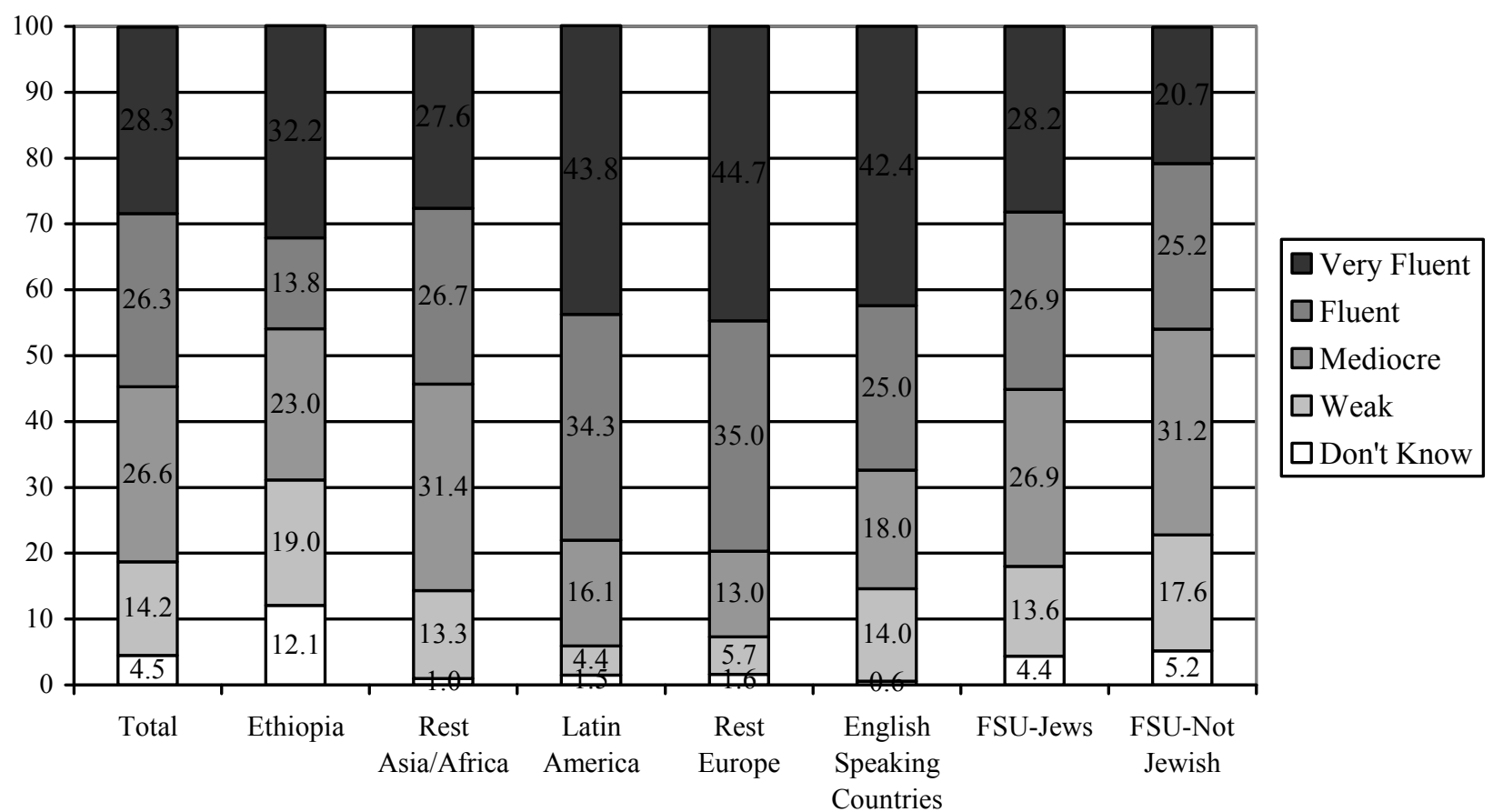


Figure 2.

Percent Fluent or Very Fluent in Hebrew by Country/Area of Origin and Tenure in Israel

\begin{tabular}{|c|c|c|c|c|c|c|c|c|c|}
\hline \multirow{5}{*}{ 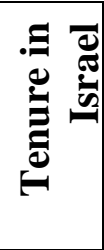 } & $17-20$ & 65.6 & 63.2 & 70.3 & 85.0 & 92.4 & 81.4 & 63.0 & 71.7 \\
\hline & 13-16 & 55.1 & 43.8 & 65.5 & 78.3 & 77.4 & 88.5 & 50.4 & 54.5 \\
\hline & $9-12$ & 42.1 & 24.0 & 66.7 & 86.2 & 85.7 & 53.8 & 41.0 & 36.2 \\
\hline & 6-8 & 39.1 & 23.1 & 22.3 & 76.9 & 78.3 & 70.9 & 24.6 & 26.9 \\
\hline & 3-5 & 28.8 & 12.0 & 23.1 & 55.0 & 25.0 & 43.2 & 23.1 & 19.0 \\
\hline & & 矛 & 营 & 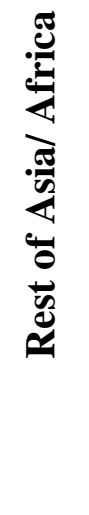 & 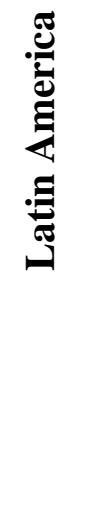 & 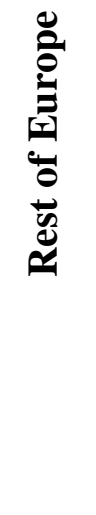 & 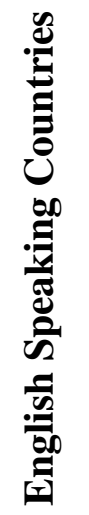 & 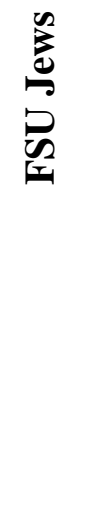 & 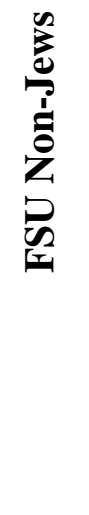 \\
\hline
\end{tabular}


Figure 3.

Employment Status (working) by Country/Area of Origin

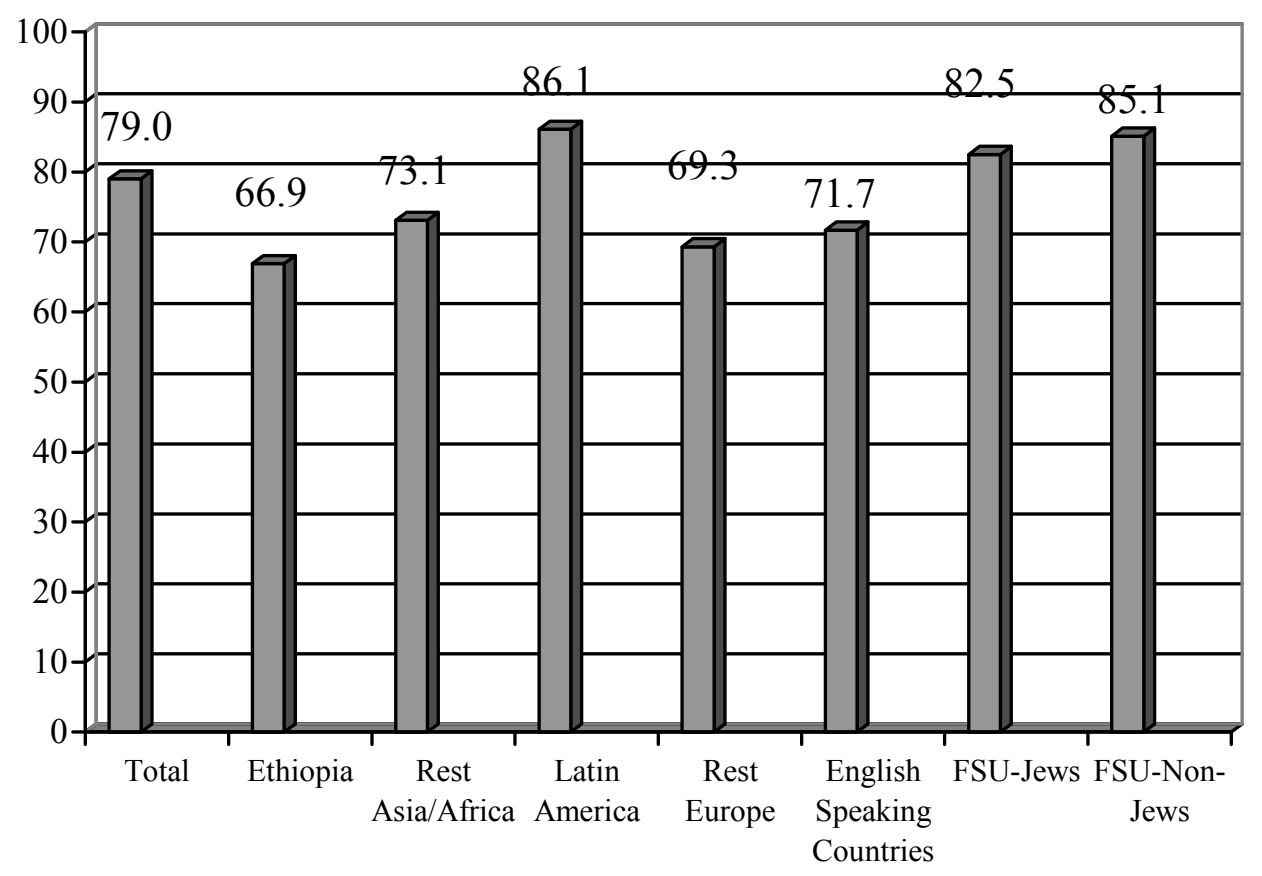


Figure 4.

Mean Annual Earnings among Immigrants in Israel, 2010_(NIS)

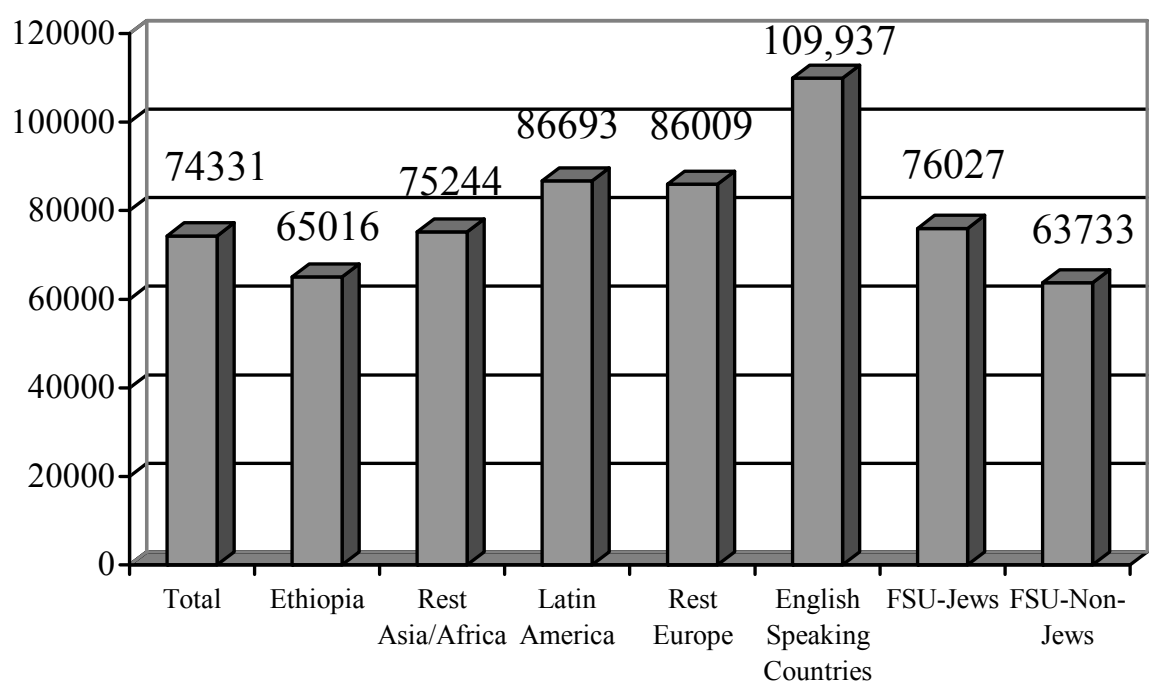


Table 1.

Definitions and Summary Statistics for Analysis Variables

\begin{tabular}{|c|c|c|}
\hline Variable $^{\mathrm{a}}$ & Definition & \begin{tabular}{|l|} 
Percentages/ \\
Mean (SD) \\
\end{tabular} \\
\hline \multicolumn{3}{|l|}{ Age at immigration } \\
\hline $6-14$ & $=1$ for $6-14$ years old at immigration & 11.1 \\
\hline $15-19$ & $=1$ for $15-19$ years old at immigration & 9.3 \\
\hline $20-24$ & $=1$ for $20-24$ years old at immigration & 13.0 \\
\hline $35-44$ & $=1$ for $35-44$ years old at immigration & 21.9 \\
\hline $45-54$ & $=1$ for $45-54$ years old at immigration & 13.2 \\
\hline $55-64$ & $=1$ for $55-64$ years old at immigration & 7.0 \\
\hline $65 \&$ over & $=1$ for $65-74$ years old at immigration & 0.7 \\
\hline Tenure & Years spent in Israel & $12.7(4.68)$ \\
\hline \multicolumn{3}{|c|}{\begin{tabular}{|l|l} 
Main reason for immigration & \\
\end{tabular}} \\
\hline Pull religious/national & $\begin{array}{l}=1 \text { for main reason for immigration }- \\
\text { Zionism or desire to live in a Jewish state }\end{array}$ & 23.5 \\
\hline \multicolumn{3}{|c|}{ 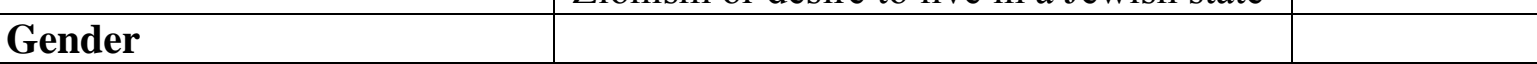 } \\
\hline Female & $=1$ for female & 54.7 \\
\hline \multicolumn{3}{|l|}{ Marital status } \\
\hline Married, spouse same country & $\begin{array}{l}=1 \text { for married person with spouse from } \\
\text { same country of origin }\end{array}$ & 76.6 \\
\hline $\begin{array}{l}\text { Married, spouse different } \\
\text { country }\end{array}$ & $\begin{array}{l}=1 \text { for married persons with spouse from } \\
\text { different country of origin }\end{array}$ & 2.8 \\
\hline \multicolumn{3}{|l|}{ Children } \\
\hline Born in Israel & $=1$ if children only born in Israel & 30.7 \\
\hline Born in Israel and abroad & $=1$ if children born in Israel and abroad & 6.2 \\
\hline Born abroad & $=1$ if children only born abroad & 8.1 \\
\hline \multicolumn{3}{|l|}{ Education } \\
\hline MA or above & $=1$ for MA or higher & 19.8 \\
\hline BA or equivalent & $=1$ for $\mathrm{BA}$ degree & 21.9 \\
\hline Post-secondary diploma & $=1$ for post-secondary education & 22.0 \\
\hline $\begin{array}{l}\text { High-school with no } \\
\text { matriculation }\end{array}$ & $\begin{array}{l}=1 \text { for high school with no matriculation } \\
\text { or less education }\end{array}$ & 16.6 \\
\hline Linguistic distance & $\begin{array}{l}\text { Linguistic distance between mother } \\
\text { tongue and Hebrew }\end{array}$ & $99.2(4.82)$ \\
\hline Nativity concentration & $\begin{array}{l}\text { Percentage of persons from the same area } \\
\text { of origin living in } \mathrm{R} \text { town of residence }\end{array}$ & $14.9(12.59)$ \\
\hline $\begin{array}{l}\text { Hebrew language studies } \\
\text { (ulpan) }\end{array}$ & $\begin{array}{l}\text { Months spent in Hebrew language studies } \\
\text { (ulpan) }\end{array}$ & $2.5(1.95)$ \\
\hline \multicolumn{3}{|l|}{ Employment status } \\
\hline Employed & $=1$ for persons currently employed & 74.9 \\
\hline
\end{tabular}

${ }^{a}$ Reference categories are as follows: age at immigration - 25-34; main reason for immigration - pull religious-national; gender - male; marital status - not married; children-no children under the age of 18 at home; education - high school with matriculation; employment status- currently not working. 
Table 2.

Ordered Logit Coefficients from the Regression of Hebrew-Speaking Proficiency on Immigration Factors, Sociodemographic Characteristics, Language Background, and Origin among Immigrants in Israel, 2010

\begin{tabular}{|c|c|c|c|c|}
\hline Independent Variables ${ }^{\mathrm{a}}$ & Jewish & ample & Total & ample \\
\hline Immigration factors & $\begin{array}{c}\text { Logit } \\
\text { Coefficient }\end{array}$ & S.E. & $\begin{array}{c}\text { Logit } \\
\text { Coefficient }\end{array}$ & S.E. \\
\hline Age at immigration & & & & \\
\hline $6-14$ & $3.979 * * *$ & $(0.218)$ & $3.903 * * *$ & $(0.186)$ \\
\hline $15-19$ & $2.138 * * *$ & $(0.167)$ & $2.319 * * *$ & $(0.145)$ \\
\hline $20-24$ & $1.421 * * *$ & $(0.140)$ & $1.284 * * *$ & $(0.117)$ \\
\hline $35-44$ & $-1.071 * *$ & $(0.119)$ & $-1.157 * * *$ & $(0.104)$ \\
\hline $45-54$ & $-2.171 * * *$ & $(0.143)$ & $-2.292 * * *$ & $(0.126)$ \\
\hline $55-64$ & $-3.543 * * *$ & $(0.196)$ & $-3.595 * * *$ & $(0.167)$ \\
\hline $65+$ & $-3.883 * * *$ & $(0.499)$ & $-4.131 * * *$ & $(0.448)$ \\
\hline Tenure & $0.057 * * *$ & $(0.011)$ & $0.065 * * *$ & $(0.009)$ \\
\hline $\begin{array}{l}\text { Main reason for migration } \\
\text { religious/national }\end{array}$ & $0.179 *$ & $(0.093)$ & $0.158^{\mathrm{i}}$ & $(0.087)$ \\
\hline $\begin{array}{l}\text { Sociodemographic } \\
\text { characteristics }\end{array}$ & & & & \\
\hline Gender & & & & \\
\hline Female & $0.195^{*}$ & $(0.080)$ & $0.210 * *$ & $(0.070)$ \\
\hline Marital status & & & & \\
\hline $\begin{array}{l}\text { Married, spouse } \\
\text { from same area of origin }\end{array}$ & -0.011 & $(0.108)$ & -0.057 & $(0.093)$ \\
\hline $\begin{array}{l}\text { Married, spouse from } \\
\text { Different area of origin }\end{array}$ & 0.296 & $(0.243)$ & 0.191 & $(0.232)$ \\
\hline Children & & & & \\
\hline $\begin{array}{l}\text { Children born in } \\
\text { Israel }\end{array}$ & 0.062 & $(0.102)$ & 0.041 & $(0.090)$ \\
\hline $\begin{array}{l}\text { Children born in } \\
\text { Israel and abroad }\end{array}$ & -0.187 & $(0.197)$ & -0.253 & $(0.158)$ \\
\hline Children born abroad & $-0.364^{*}$ & $(0.165)$ & $-0.428 * * *$ & $(0.133)$ \\
\hline Education & & & & \\
\hline No matriculation & $-0.529 * * *$ & $(0.139)$ & $-0.524 * * *$ & $(0.119)$ \\
\hline $\begin{array}{l}\text { Post-secondary } \\
\text { diploma }\end{array}$ & $0.344 * *$ & $(0.127)$ & $0.300 * *$ & $(0.107)$ \\
\hline BA or equivalent & $0.843 * * *$ & $(0.133)$ & $0.929 * * *$ & $(0.112)$ \\
\hline M.A. degree or higher & $1.297 * * *$ & $(0.135)$ & $1.345 * * *$ & $(0.117)$ \\
\hline Language background & & & & \\
\hline $\begin{array}{l}\text { Hebrew language studies } \\
\text { (ulpan) }\end{array}$ & $0.079 * * *$ & $(0.022)$ & $0.111 * * *$ & $(0.019)$ \\
\hline Linguistic distance & -0.011 & $(0.012)$ & -0.016 & $(0.011)$ \\
\hline Nativity concentration & $-0.010 * *$ & $(0.004)$ & $-0.011 * * *$ & $(0.003)$ \\
\hline Origin & & & & \\
\hline Ethiopia & $-0.845 * * *$ & $(0.239)$ & $-0.926 * * *$ & $(0.224)$ \\
\hline Rest Asia/Africa & $1.589 * * *$ & $(0.303)$ & $1.630 * * *$ & $(0.298)$ \\
\hline Latin America & $2.145 * * *$ & $(0.226)$ & $2.235 * * *$ & $(0.222)$ \\
\hline
\end{tabular}




\begin{tabular}{|l|l|l|l|l|}
\hline Rest Europe & 0.423 & $(0.266)$ & $0.445^{\mathrm{i}}$ & $(0.258)$ \\
\hline English speaking countries & $0.610^{* *}$ & $(0.194)$ & $0.676^{* * *}$ & $(0.188)$ \\
\hline FSU-non-Jews & - & - & $-0.188^{*}$ & $(0.088)$ \\
\hline Pseudo R ${ }^{2}$ (Nagelkerke) & \multicolumn{2}{|c|}{$58.2 \%$} & \multicolumn{2}{c|}{$59.4 \%$} \\
\hline Total (N) & \multicolumn{2}{|c|}{2,882} & \multicolumn{2}{c|}{3,790} \\
\hline
\end{tabular}

${ }^{\mathrm{i}} \mathrm{p}<0.10 ; * \mathrm{P}<0.05 ; * * \mathrm{P}<0.01 ; * * * \mathrm{P}<0.001$

a) Numbers in parentheses are standard errors.

b) The reference categories are: age at immigration - 25-34; main reason for immigration - other than religious/national; gender - male; marital status - not married; children - no children; education - high school matriculation; origin - FSU (Jews). 
Table 3.

Logistic Regression (Unstandardized Coefficients B) of Employment Status on Immigration Factors, Sociodemographic Characteristics, Hebrew Language Proficiency, and Origin among Immigrants in Israel, 2010

\begin{tabular}{|c|c|c|c|c|}
\hline Independent Variables ${ }^{\mathrm{a}}$ & \multicolumn{2}{|c|}{ Jewish Sample } & \multicolumn{2}{|c|}{ Total Sample } \\
\hline Immigration factors & $\begin{array}{l}\text { Unstandardized } \\
\text { Coefficient (B) }\end{array}$ & S.E. & $\begin{array}{l}\text { Unstandardized } \\
\text { Coefficient (B) }\end{array}$ & S.E. \\
\hline \multicolumn{5}{|l|}{ Age at immigration } \\
\hline $6-14$ & $0.711 * *$ & $(0.287)$ & 0.043 & $(0.238)$ \\
\hline $15-19$ & $0.895 * *$ & $(0.290)$ & $0.634^{*}$ & $(0.255)$ \\
\hline $20-24$ & -0.189 & $(0.200)$ & -0.252 & $(0.180)$ \\
\hline $35-44$ & $-0.563 * * *$ & $(0.167)$ & $-0.518 * * *$ & $(0.154)$ \\
\hline $45-54$ & $-1.320 * * *$ & $(0.222)$ & $-1.620 * * *$ & $(0.192)$ \\
\hline $55-64$ & $-2.087 * * *$ & $(0.477)$ & $-2.165 * * *$ & $(0.367)$ \\
\hline Tenure & $-0.055 * * *$ & $(0.015)$ & $-0.055 * * *$ & $(0.014)$ \\
\hline $\begin{array}{l}\text { Main reason for immigration } \\
\text { religious/national }\end{array}$ & 0.154 & $(0.138)$ & $0.295^{*}$ & $(0.128)$ \\
\hline \multicolumn{5}{|l|}{$\begin{array}{l}\text { Sociodemographic } \\
\text { characteristics }\end{array}$} \\
\hline \multicolumn{5}{|l|}{ Gender } \\
\hline Female & $-0.831 * * *$ & $(0.189)$ & $-0.766 * * *$ & $(0.171)$ \\
\hline \multicolumn{5}{|l|}{ Marital status } \\
\hline Not-married & -0.113 & $(0.227)$ & 0.021 & $(0.203)$ \\
\hline \multicolumn{5}{|l|}{ Children } \\
\hline No children & $-0.463^{*}$ & $(0.195)$ & $-0.390^{*}$ & $(0.176)$ \\
\hline \multicolumn{5}{|l|}{ Education } \\
\hline No matriculation & $-0.338^{\mathrm{i}}$ & $(0.199)$ & $-0.320^{i}$ & $(0.173)$ \\
\hline Post-secondary diploma & -0.072 & $(0.186)$ & 0.001 & $(0.162)$ \\
\hline BA or equivalent & -0.041 & $(0.189)$ & -0.037 & $(0.163)$ \\
\hline M.A. degree or higher & 0.209 & $(0.202)$ & 0.163 & $(0.179)$ \\
\hline \multicolumn{5}{|l|}{ Hebrew-language proficiency } \\
\hline Very fluent & $0.452 *$ & $(0.193)$ & $0.400^{*}$ & $(0.177)$ \\
\hline Fluent & $0.319 *$ & $(0.158)$ & $0.320 *$ & $(0.145)$ \\
\hline Weak & $-0.634 * * *$ & $(0.185)$ & $-0.641 * * *$ & $(0.161)$ \\
\hline Don't know & $-1.174 * * *$ & $(0.326)$ & $-0.851 * *$ & $(0.271)$ \\
\hline Nativity concentration & 0.001 & $(0.005)$ & -0.002 & $(0.005)$ \\
\hline \multicolumn{5}{|l|}{ Origin } \\
\hline Ethiopia & 0.016 & $(0.295)$ & 0.061 & $(0.274)$ \\
\hline Rest Asia/Africa & $-0.597^{\mathrm{i}}$ & $(0.318)$ & $-0.635^{*}$ & $(0.312)$ \\
\hline Latin America & -0.300 & $(0.300)$ & -0.322 & $(0.274)$ \\
\hline Rest Europe & $-1.103 * * *$ & $(0.269)$ & $-1.100 * * *$ & $(0.261)$ \\
\hline English speaking countries & $-0.620 *$ & $(0.254)$ & $-0.638 * *$ & $(0.247)$ \\
\hline FSU-non-Jews & - & - & $0.341 *$ & $(0.143)$ \\
\hline \multicolumn{5}{|l|}{ Interaction terms } \\
\hline Female*not married & -0.319 & $(0.283)$ & -0.363 & $(0.252)$ \\
\hline Female*no children & $0.687 * *$ & $(0.240)$ & $0.528^{*}$ & $(0.214)$ \\
\hline Pseudo R ${ }^{2}$ (Nagelkerke) & $18.4 \%$ & & $17.4 \%$ & \\
\hline
\end{tabular}




\begin{tabular}{|l|c|c|}
\hline Total $(\mathrm{N})$ & 2,185 & 2,854 \\
\hline
\end{tabular}

${ }^{\mathrm{i}} \mathrm{p}<0.10 ; * \mathrm{P}<0.05 ; * * \mathrm{P}<0.01 ; * * * \mathrm{P}<0.001$

a) Numbers in parentheses are standard errors.

b) The reference categories are: age at immigration - 25-34; main reason for immigration - other than religious/national; gender - male; marital status - married; children - have children; education - high school matriculation; Hebrew-language proficiency-mediocre; origin - FSU (Jews). 
Table 4.

OLS Regression (Unstandardized Coefficients [B]) of Earnings on Immigration

Factors, Sociodemographic Characteristics, Class Work, Hebrew-Language

Proficiency, and Origin among Immigrants in Israel, 2010

\begin{tabular}{|c|c|c|c|c|}
\hline Independent Variables ${ }^{\mathrm{a}}$ & \multicolumn{2}{|c|}{ Jewish Sample } & \multicolumn{2}{|c|}{ Total Sample } \\
\hline Immigration factors & $\begin{array}{l}\text { Unstandardized } \\
\text { Coefficient (B) }\end{array}$ & S.E. & $\begin{array}{l}\text { Unstandardized } \\
\text { Coefficient (B) }\end{array}$ & S.E. \\
\hline \multicolumn{5}{|l|}{ Age at immigration } \\
\hline $6-14$ & 0.131 & $(0.122)$ & 0.173 & $(0.112)$ \\
\hline $15-19$ & -0.098 & $(0.121)$ & 0.010 & $(0.106)$ \\
\hline $20-24$ & $0.286 * *$ & $(0.109)$ & 0.084 & $(0.092)$ \\
\hline $35-44$ & -0.023 & $(0.094)$ & 0.066 & $(0.082)$ \\
\hline $45-54$ & -0.149 & $(0.132)$ & -0.132 & $(0.115)$ \\
\hline $55-64$ & -0.142 & $(0.296)$ & -0.113 & $(0.249)$ \\
\hline Tenure & $0.029 * * *$ & $(0.008)$ & $0.032 * * *$ & $(0.007)$ \\
\hline $\begin{array}{l}\text { Main reason for immigration } \\
\text { religious/national }\end{array}$ & 0.025 & $(0.078)$ & 0.018 & $(0.074)$ \\
\hline \multicolumn{5}{|l|}{$\begin{array}{l}\text { Sociodemographic } \\
\text { characteristics }\end{array}$} \\
\hline \multicolumn{5}{|l|}{ Gender } \\
\hline Female & -0.090 & $(0.094)$ & -0.086 & $(0.082)$ \\
\hline \multicolumn{5}{|l|}{ Marital status } \\
\hline Not-married & 0.141 & $(0.110)$ & 0.105 & $(0.099)$ \\
\hline \multicolumn{5}{|l|}{ Children } \\
\hline No children & $0.228^{*}$ & $(0.094)$ & $0.244 * *$ & $(0.084)$ \\
\hline \multicolumn{5}{|l|}{ Education } \\
\hline No matriculation & 0.108 & $(0.109)$ & 0.119 & $(0.095)$ \\
\hline Post-secondary diploma & $0.195^{\mathrm{i}}$ & $(0.102)$ & $0.222 * *$ & $(0.086)$ \\
\hline BA or equivalent & $0.186^{\mathrm{i}}$ & $(0.102)$ & $0.152 \mathrm{i}$ & $(0.087)$ \\
\hline M.A. degree or higher & -0.122 & $(0.104)$ & -0.110 & $(0.093)$ \\
\hline \multicolumn{5}{|l|}{ Hebrew-language proficiency } \\
\hline Very fluent & 0.052 & $(0.101)$ & 0.105 & $(0.091)$ \\
\hline Fluent & $0.287 * * *$ & $(0.087)$ & $0.317 * * *$ & $(0.075)$ \\
\hline Weak & $0.240^{\mathrm{i}}$ & $(0.142)$ & 0.118 & $(0.112)$ \\
\hline Don't know & 0.091 & $(0.291)$ & -0.038 & $(0.228)$ \\
\hline Nativity concentration & $0.008 * *$ & $(0.003)$ & $0.005^{*}$ & $(0.002)$ \\
\hline \multicolumn{5}{|l|}{ Origin } \\
\hline Ethiopia & -0.011 & $(0.160)$ & -0.024 & $(0.157)$ \\
\hline Rest Asia/Africa & 0.273 & $(0.208)$ & 0.259 & $(0.209)$ \\
\hline Latin America & 0.050 & $(0.172)$ & 0.016 & $(0.171)$ \\
\hline Rest Europe & 0.281 & $(0.187)$ & 0.250 & $(0.186)$ \\
\hline English speaking countries & $0.392 *$ & $(0.163)$ & $0.430 * *$ & $(0.161)$ \\
\hline FSU-non-Jews & - & - & $-0.163 *$ & $(0.072)$ \\
\hline \multicolumn{5}{|l|}{ Interaction terms } \\
\hline Female*not married & $-0.352 *$ & $(0.152)$ & $-0.298 *$ & $(0.135)$ \\
\hline Female*no children & -0.022 & $(0.125)$ & 0.013 & $(0.110)$ \\
\hline Pseudo R ${ }^{2}$ (Nagelkerke) & $5.5 \%$ & & $6.4 \%$ & \\
\hline
\end{tabular}




\begin{tabular}{|l|c|c|}
\hline Total $(\mathrm{N})$ & 1,305 & 1,731 \\
\hline
\end{tabular}

${ }^{\mathrm{i}} \mathrm{p}<0.10 ; * \mathrm{P}<0.05 ; * * \mathrm{P}<0.01 ; * * * \mathrm{P}<0.001$

a) Numbers in parentheses are standard errors.

b) The reference categories are: age at immigration - 25-34; main reason for immigration - other than religious/national; gender - male; marital status - married; children - have children; education - high school matriculation; Hebrew-language proficiency-mediocre; origin - FSU (Jews). 
Appendix A1. Reasons for Migration by Country/Area of Origin

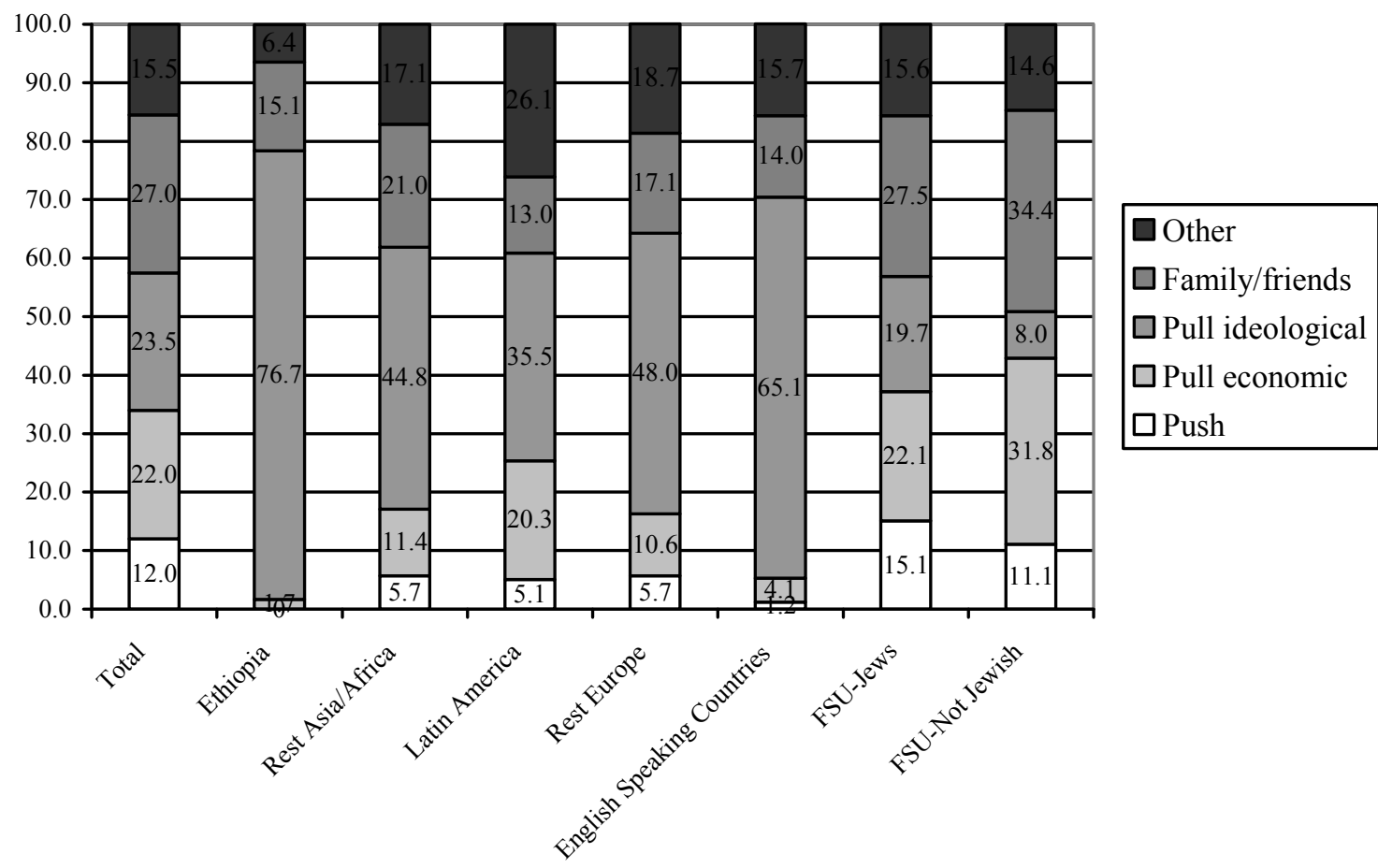


Appendix A2

Coefficients from Regressions on Non-Jewish Immigrants from the FSU

\begin{tabular}{|c|c|c|c|c|c|c|}
\hline \multirow{2}{*}{$\begin{array}{l}\text { Independent Variables }^{\mathrm{a}} \\
\text { Immigration factors }\end{array}$} & \multicolumn{2}{|c|}{$\begin{array}{l}\text { Hebrew-Speaking } \\
\text { Proficiency }\end{array}$} & \multicolumn{2}{|c|}{ Employment Status } & \multicolumn{2}{|c|}{ Earnings } \\
\hline & $\begin{array}{c}\text { Ordinal } \\
\text { Regression }\end{array}$ & S.E. & $\begin{array}{c}\text { Logistic } \\
\text { Regression }\end{array}$ & S.E. & $\begin{array}{c}\text { OLS } \\
\text { Regression }\end{array}$ & S. E. \\
\hline \multicolumn{7}{|l|}{ Age at immigration } \\
\hline $6-14$ & $3.739 * * *$ & $(0.368)$ & $-2.632 * * *$ & $(0.569)$ & $0.684^{*}$ & $(0.315)$ \\
\hline $15-19$ & $2.841 * * *$ & $(0.297)$ & -0.753 & $(0.604)$ & 0.295 & $(0.224)$ \\
\hline $20-24$ & $0.982 * * *$ & $(0.219)$ & -0.676 & $(0.463)$ & $-0.321^{\mathrm{i}}$ & $(0.172)$ \\
\hline $35-44$ & $-1.575^{* *}$ & $(0.231)$ & 0.382 & $(0.552)$ & $0.395^{*}$ & $(0.175)$ \\
\hline $45-54$ & $-2.814 * * *$ & $(0.278)$ & $-2.662 * * *$ & $(0.450)$ & -0.129 & $(0.233)$ \\
\hline $55-64$ & $-3.961 * * *$ & $(0.330)$ & $-2.565 * * *$ & $(0.673)$ & -0.116 & $(0.460)$ \\
\hline $65+$ & $-5.271 * * *$ & $(1.034)$ & - & - & - & - \\
\hline Tenure & $0.084 * * *$ & $(0.020)$ & -0.024 & $(0.040)$ & $0.045 * *$ & $(0.017)$ \\
\hline $\begin{array}{l}\text { Main reason for migration } \\
\text { religious/national }\end{array}$ & $0.081^{*}$ & $(0.249)$ & $1.158 * *$ & $(0.377)$ & 0.097 & $(0.220)$ \\
\hline \multicolumn{7}{|l|}{$\begin{array}{l}\text { Sociodemographic } \\
\text { characteristics }\end{array}$} \\
\hline \multicolumn{7}{|l|}{ Gender } \\
\hline Female & $0.328 *$ & $(0.149)$ & -0.505 & $(0.447)$ & 0.027 & $(0.172)$ \\
\hline \multicolumn{7}{|l|}{ Marital status } \\
\hline $\begin{array}{l}\text { Married, spouse } \\
\text { from same area of origin }\end{array}$ & -0.194 & $(0.190)$ & - & - & - & - \\
\hline $\begin{array}{l}\text { Married, spouse from } \\
\text { Different area of origin }\end{array}$ & -0.558 & $(0.884)$ & - & - & - & - \\
\hline Not-married & - & - & 0.372 & $(0.502)$ & 0.028 & $(0.232)$ \\
\hline \multicolumn{7}{|l|}{ Children } \\
\hline $\begin{array}{l}\text { Children born in } \\
\text { Israel }\end{array}$ & -0.064 & $(0.195)$ & - & - & - & - \\
\hline $\begin{array}{l}\text { Children born in } \\
\text { Israel and abroad }\end{array}$ & -0.431 & $(0.276)$ & - & - & - & - \\
\hline Children born abroad & $-0.550 *$ & $(0.233)$ & - & - & - & - \\
\hline No children & - & - & 0.429 & $(0.458)$ & $0.334^{\mathrm{i}}$ & $(0.184)$ \\
\hline \multicolumn{7}{|l|}{ Education } \\
\hline No matriculation & -0.380 & $(0.242)$ & $-0.004 * * *$ & $(0.414)$ & -0.024 & $(0.200)$ \\
\hline $\begin{array}{l}\text { Post-secondary } \\
\text { diploma }\end{array}$ & 0.190 & $(0.200)$ & $0.067 * *$ & $(0.380)$ & 0.167 & $(0.162)$ \\
\hline BA or equivalent & $1.301 * * *$ & $(0.217)$ & -0.374 & $(0.366)$ & -0.025 & $(0.174)$ \\
\hline M.A. degree or higher & $1.744 * * *$ & $(0.254)$ & $-0.230 * * *$ & $(0.449)$ & -0.010 & $(0.226)$ \\
\hline \multicolumn{7}{|l|}{ Language background } \\
\hline $\begin{array}{l}\text { Hebrew language studies } \\
\text { (ulpan) }\end{array}$ & $0.218 * * *$ & $(0.040)$ & - & - & - & - \\
\hline \multicolumn{7}{|l|}{$\begin{array}{l}\text { Hebrew-language } \\
\text { proficiency }\end{array}$} \\
\hline Very fluent & - & - & 0.504 & $(0.489)$ & 0.190 & $(0.211)$ \\
\hline Fluent & - & - & $0.836^{*}$ & $(0.425)$ & $0.420 * *$ & $(0.154)$ \\
\hline Weak & - & - & -0.541 & $(0.378)$ & -0.005 & $(0.186)$ \\
\hline Don't know & - & - & 0.023 & $(0.624)$ & -0.181 & $(0.371)$ \\
\hline \multicolumn{7}{|l|}{ Interaction terms } \\
\hline Female*not married & - & - & -0.187 & $(0.624)$ & -0.349 & $(0.307)$ \\
\hline Female*no children & - & - & -0.501 & $(0.543)$ & -0.112 & $(0.242)$ \\
\hline Pseudo R² (Nagelkerke) & \multicolumn{2}{|c|}{$63.5 \%$} & \multicolumn{2}{|c|}{$30.6 \%$} & \multicolumn{2}{|c|}{$10.4 \%$} \\
\hline Total $(\mathrm{N})$ & \multicolumn{2}{|c|}{908} & \multicolumn{2}{|c|}{669} & \multicolumn{2}{|c|}{426} \\
\hline
\end{tabular}

${ }^{\mathrm{i}} \mathrm{p}<0.10 ; * \mathrm{P}<0.05 ; * * \mathrm{P}<0.01 ; * * * \mathrm{P}<0.001$

a) Numbers in parentheses are standard errors.

b) For reference categories see footnote (b) of Tables 2, 3, and 4, respectively. 